\title{
Management of Business Processes and Export-Import Activity of Industrial Enterprises in the Digital Economy
}

\author{
OLHA PYROH ${ }^{1}$, MARYNA PROKOPENKO ${ }^{2}$, LIANA CHERNOBAY ${ }^{3}$, ROMAN KOVALENKO $^{4}$, \\ YULIIA PAPIZH ${ }^{5}$, YEVHENIIA SYTA ${ }^{6}$ \\ ${ }^{1,3}$ Department of Management and International Business, LVIV POLYTECHNIC NATIONAL UNIVERSITY, \\ UKRAINE. \\ ${ }^{2}$ Department of Management, KYIV NATIONAL UNIVERSITY OF TECHNOLOGY AND DESIGN, UKRAINE. \\ E-mail: writetoprokopenko@gmail.com \\ ${ }^{4}$ Department of International Economic Relations named after Arthur Golikov V.N., KARAZIN KHARKIV \\ NATIONAL UNIVERSITY, UKRAINE. \\ 5Department of Management, NATIONAL TECHNICAL UNIVERSITY “DNIPRO POLYTECHNIC". UKRAINE. \\ ${ }^{6}$ Department of Public Management and Administration, ODESSA NATIONAL POLYTECHNIC UNIVERSITY, \\ UKRAINE.
}

\begin{abstract}
In the conditions of the digital economy and integration in the international space, the management of business processes and the formation of a rational sequence of planning such activities are becoming increasingly important for enterprises engaged in export-import activities. The authors investigated the features of business process management of an industrial enterprise and their export-import activity management features. For example, key indicators of efficiency and indicators of productivity of business process of the industrial enterprise, to investigate tendencies of export-import activity of the industrial enterprises are considered.

The study allowed to offer tools for business process management and export-import activities of industrial enterprises in the digital economy, namely the Algorithm for the formation of the market strategy of the enterprise to begin the implementation of the export-import activity, the indicator of the integrated economic effect from the export-import activity and the Scenario of management of export-import activity of industrial enterprises in interrelation with the management of business processes, which are used as a basis for strategic and operational planning, and later will be used to control plans.
\end{abstract}

Keywords: business processes, digital economy, export-import activity, industrial enterprises

JEL Classification: L21, L25, L29

Received: 3 May 2021

Accepted: 8 May 2021 


\section{Introduction.}

The restructuring of Ukraine's economy on a market basis is accompanied by the growing involvement of our country in the existing system of world economic relations. The integration of Ukraine's economy into the world economy and its participation in various types of international entrepreneurship increase the role and importance of the enterprise's business process management and export-import activities. The export-import activity of the enterprise, which is carried out by conducting commercial operations, is an essential element of the mechanism of management of foreign economic relations. Export-import activity is manifested in the forms of exchange of material goods, services, products of intellectual labour, the results of production and technical cooperation between countries.

In the context of the digital economy and integration in the international space, the management of business processes and the formation of a rational sequence of planning such activities is becoming increasingly important for enterprises engaged in foreign economic activity. This type of management activities contributes to additional profits through the fuller use of the benefits of international labour and international integration and identifying prospects and possible options for the development of the foreign economic activity of organizations. That is why the technology of business process management and export-import activities of industrial enterprises in the digital economy today is becoming especially relevant.

\section{Theoretical Basis.}

\subsection{Management of Business Processes.}

Implementation of the course of the digital economy, freedom of trade is becoming the dominant global trend, as it determines the number of potential advantages for the country: increasing national income as a result of growing resources and factors of production involved in international trade; transition from traditional trade to higher forms of cooperation (scientific and technical cooperation, industrial integration), etc.; increasing the degree of mobility of national factors of production; accelerating the formation of market infrastructure in the country [1-3]. All this can happen by managing business processes and export-import activities of industrial enterprises in a digital economy.

It is necessary to consider in detail the essence, components of the business process and its place in the structure of the enterprise. Fig. 1 shows simplified levels of detail of business processes.

Operation - the minimum part for the analysis of the activities of an individual employee, is carried out "automatically" by him without conscious control.

Action - several operations performed in a row; after completion, the performer exercises conscious control (it is necessary to focus on the professional level, not on the level of a beginner, emphasizing operations and actions).

Procedure - is several consecutive actions performed by a particular performer. The procedure should have a result: a document, product or information (oral communication, e-mail, message, etc.), depending on the process.

A business process is a set of interrelated procedures performed by different entities, which leads to a complete and meaningful result for the company-for example, a signed contract, goods in stock, etc.

Area of activity - is an extended segment of the organization, which consists of one or more significant groups of business processes. 
Figure 1. Detailed levels of business processes [4]

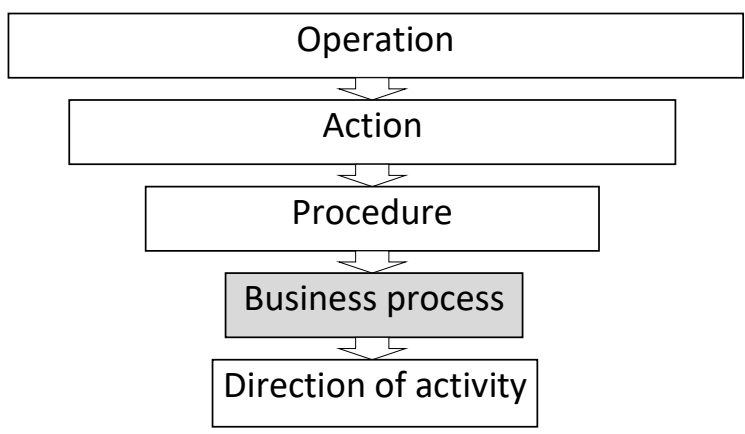

The company has many processes. M. Porter [5] proposes a classification of processes based on their role in creating added value (each process must make an additional contribution to the previous process in the value of the final product). According to this criterion, all processes are divided into three groups:

- main processes - directly related to production;

- auxiliary processes - support the primary processes (procurement, personnel management, etc.);

- management processes - include the processes of setting goals and creating conditions for their achievement.

All these processes are interconnected and form a single system.

An important factor in any business process will be its efficiency, and the task of management is to constantly improve the performance of the business process.

In order to offer customers high-quality products, any company, especially an industrial one, needs to control the processes of their creation. Well-thought-out and well-established business processes ensure a high level of quality and, accordingly, the products will be in demand both in the domestic and foreign markets. The main task of management is to accurately determine the essential components of the process for its subsequent assessment, optimization, and implementation standards [6-7].

When evaluating the indicators of business processes, it should be noted that one of the most critical operational indicators and criteria for evaluating any company should be an indicator of the duration of the process completion cycle. The total cycle time is the amount of time that elapses from the moment the task starts to the moment it ends. For example, the customer service cycle duration is calculated from the moment the order is accepted from the customer until it is delivered to the customer or the collected order is released from the warehouse. When drawing up a company's strategy, it can set one of the goals - to become the number one company on the market in terms of order execution cycle time and bring the execution time to XX days. This indicator can become a competitive advantage for the company. Time is a critical metric for completing any task as it relates to customer satisfaction and the cost of performing the service. This indicator can be included in virtually any company in the list of key performance indicators, and it can take its rightful place along with financial performance indicators. Cycle time assessment should be carried out for all service and support services of the organization.

The effectiveness of activities can exist with the effectiveness of business processes and the persons performing them accordingly [8-9]. Process efficiency indicators will be:

- Indicators of resource costs

a. Time (cycle, duration, productivity, order fulfilment speed)

b. Material (expenses of funds, materials, assets used in the form of accounts receivable, warehouse stocks, etc.) 
- Cost of marriage

- Expenses for education, training and professional development of employees

- Efficiency in the use of resources per unit of production

a. Equipment utilization rates

b. Utilization rates of resources, raw materials and materials

c. Time spent on carrying out a unit of work or services

A company needs to have several performance metrics in its arsenal in order to make good use of human and other resources. The performance indicator is the ratio of the result and the resources spent on its achievement. The performance metrics most commonly used by companies are sales per employee; profit per employee; the number of transactions performed by one employee, etc.;

Metrics such as labour productivity ratios are most often measured by two indicators - sales revenue per employee and profit per employee. Compiling these indicators is usually built to compare these indicators in a relatively long time interval.

The biggest challenge is choosing the right standards and performance targets. For evaluating the company as a whole, sales per employee are essential; at the same time, they are absolutely meaningless for assessing the level of the department.

The business process measurement needs to be assessed from the customer's perspective.

Typically, companies view their business processes based on four distinct categories:

- development of products and services;

- generating demand;

- meeting demand;

- planning and enterprise management.

Processes are what reflects what work is done, where and when, how it will be done. Consideration should be given to those aspects and characteristics that will be important to measure for process evaluation. These measurements can be divided into the following categories:

- quality;

- quantity;

- time;

- ease of use;

- money [1].

These five categories will help define the criteria for measuring the process milestones that we believe are most important to our success. When measuring efficiency, it is necessary to consider the components of the process itself separately.

The process can be broken down into inputs, actions, outputs, results. Key performance indicators and performance indicators, being derivatives, when using such a scheme characterize the process as a whole (Fig. 2.). 
Figure 2. Definition of KPI business process "Logistics" [4]

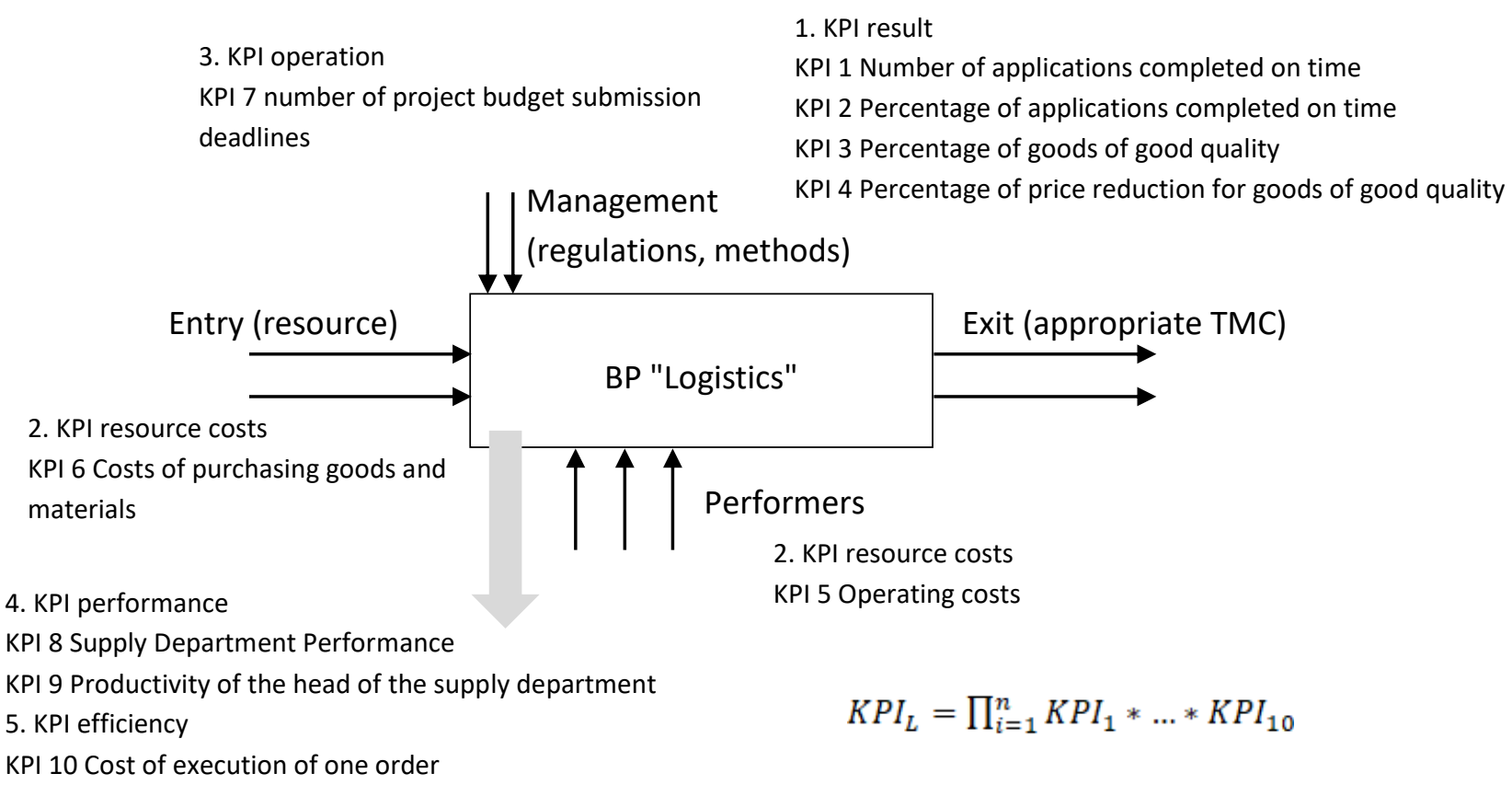

Inputs-mechanisms of this process: equipment of workplaces of employees of the supply department; employees of the supply department.

c) identification of inputs-control (rules and requirements for the process). For example, this process can be regulated by: "Instructions for acceptance and storage of raw materials, semi-finished products and materials in the warehouse"; "Requirements for goods and materials", "Methods of selection of suppliers"; "Rules for concluding a contract for the supply of raw materials"; "Sample contract", "Procurement plan".

d) evaluation of the result. Knowing the result to be obtained is necessary to quantify it - to form indicators of the result. They can be both simple and require calculations (by formula or otherwise).

e) the formation of cost indicators. Based on the inputs of the process, you can generate cost indicators.

f) formation of additional cost indicators Based on the mechanisms of the process, it is possible to form additional cost indicators.

g) the formation of performance indicators. The correctness of the process and indicators of operating costs also reflect the performance indicators.

j) the formation of performance indicators are calculated as the ratio of the result obtained over time.

I) the formation of performance indicators. The calculation of key performance indicators is based on the pre-selected KPI result and KPI costs. Performance indicators, thus, act as essential characteristics of activity. According to the principle of the ratio of costs to the result obtained, you can calculate both indicators of production efficiency and indicators of project efficiency or management efficiency indicators.

$\mathrm{KPI}$ calculation for any business process:

$$
K P I_{x}=\prod_{i=1}^{n} K P I_{1} * \ldots * K P I_{n}
$$

where $K P I_{1}, K P I_{n}-\mathrm{KPI}$ of business process components (coefficients). 
For the most important business processes or for those whose KPIs do not meet the desired value, the company can perform a correlation analysis of the impact of components to identify factors that need attention.

The introduction of KPI also becomes a clear and transparent system of motivation: because the planned and actual values are fixed, the manager is clear about what and how to motivate the employee. He, in turn, understands well under what conditions and what reward he will receive and for what he will be fined. For example, the head of the supply department: is awarded for the achievement of the planned efficiency and effectiveness indicators; fined for non-compliance with performance indicators (failure to submit the draft budget to the financial department).

The KPI of each business process is determined separately. Crucial in this process is the cooperation of a consultant (guided by the general methodology and practice of determining KPIs) and employees of the enterprise (who know the essence of this business process and can add/remove some KPIs depending on the activity, size of the enterprise, etc.). This technique takes some time but is performed almost once; when changing the strategy or goals of the enterprise KPI business processes should only be reviewed for relevance. It is also worth calculating such indicators only for basic and essential business processes.

\subsection{Management Export-Import Activity.}

Export-import activity is an essential component of the economy, without which its functioning and development can be complicated. It is the process of implementing foreign economic relations, including international trade, joint ventures, services and other cooperation.

Export and import activities in all countries are aimed at:

- promoting the equalization of economic development;

- comparability of production costs at the national and world levels;

- realization of the advantages of the international division of labour, which contributes to the growth of the efficiency of national economies.

At the enterprise level, the management of export-import activities includes solutions to strategic, production, financial, infrastructure and logistics, information and marketing issues such as:

- entering the foreign market;

- export-import deliveries of goods, services and capital;

- financial and credit operations;

- participation in joint ventures;

- international marketing;

- monitoring of national economic policy and world economic relations.

To decide on foreign economic activity and its strategically important areas, the company needs to conduct a comparative analysis of the levels of economic development of potential partners and study the political, economic and national-cultural characteristics of these countries.

According to statistics, the leaders in exports are Manufacturing industry, Wholesale and retail trade; repair of motor vehicles and motorcycles and Agriculture, Forestry and Fisheries; leaders in imports - Wholesale and retail trade; repair of motor vehicles and motorcycles, Manufacturing industry and Supply of electricity, gas, steam and air conditioning (Fig. 2).

The company's initiative to go abroad may be related to the company's internal needs or proposals from abroad. In both cases, you need to decide what type and quantity of products will be exported and imported, through which and in which countries, which markets should, above all, focus. To begin implementing export-import operations, the company needs to determine the market strategy, which allows you to choose the best option among the alternative solutions. 
Figure 2. Imports and Exports of goods by main economic entities by the number of hired workers by types of economic activity in 2019 [10]

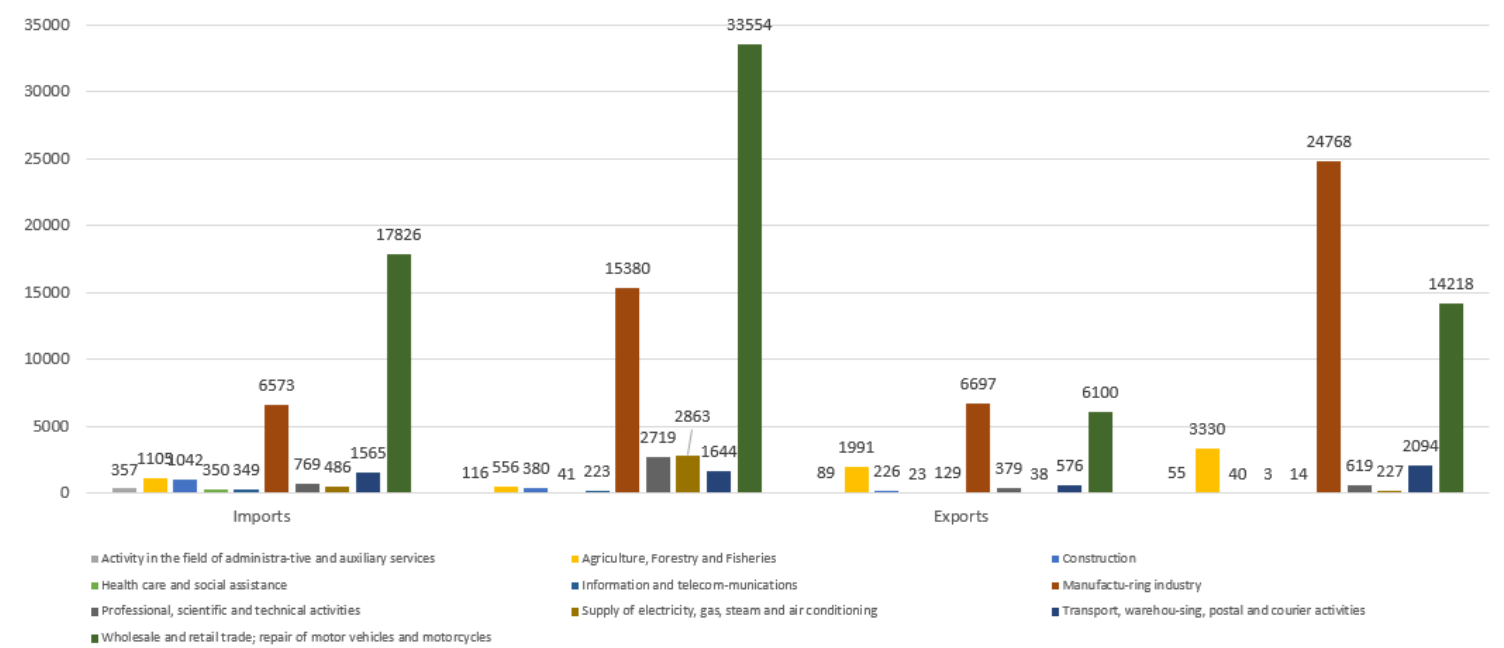

When carrying out export-import activities, the company can choose one of the following strategies [11-13]:

Innovation strategy. Their high saturation characterizes international markets, so the creation of competitive products and consumer engagement is increasingly important as one of the key success factors in competition. New products must differ from existing ones in the market either in appearance or in function. This can be achieved through innovation and significant investment in product development. Diversification strategy. This strategy means developing new activities of the enterprise, expanding the range of products and production.

Internationalization strategy. Systematic study and analysis of international markets. Reasons for the application of this strategy: increased competition, stagnation of the internal market, the desire for fuller utilization of production capacity, the need to share risk and the availability of financial benefits.

Globalization strategy. Definition of general, independent of the characteristics of individual countries, characteristics of markets and target groups. The primary strategy for selecting and processing markets in this case - product standardization.

Cooperation strategy. The rapid development of national and foreign markets forces companies to look for partners for mutually beneficial cooperation, which will strengthen market position and reach their full potential.

After developing the strategy, analyzing international markets and key competitors, it is necessary to analyze the expected results in the implementation of the strategy of export-import activities of the firm and compare them with the prospects of economic activity in the domestic market. To determine the feasibility of export-import operations is important to analyze the efficiency of these operations and only then compare with the efficiency of production and sales in the domestic market.

Having chosen one of the ways to organize export-import operations, the company searches for potential partners, which results in negotiations and signing a contract.

\section{Results.}

To begin implementing export-import operations, the company needs to determine the market strategy, which allows you to choose the best option among the alternative solutions.

The market strategy of the enterprise consists of the following stages (Fig. 3). 
Figure 3. Algorithm for the formation of the market strategy of the enterprise to begin the implementation of export-import activity (source: developed by the authors)

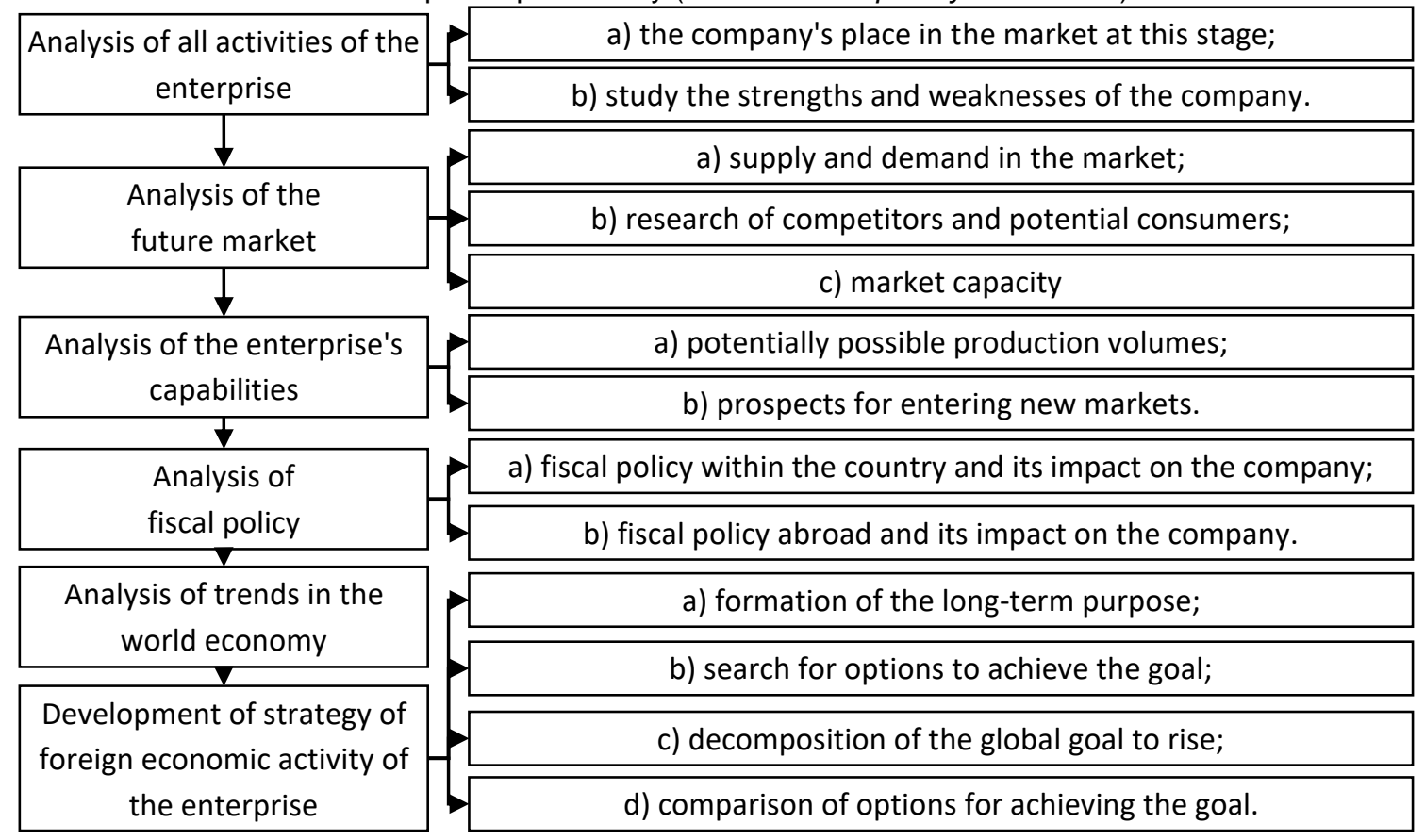

The company's strategy in export-import activity is a system of rules, measures, and techniques that will help the company function effectively in foreign markets and ensure the achievement of the company's goals.

If the company is engaged in exports and imports at the same time, then to assess its performance in the foreign market for a certain period can be calculated integrated indicators of the effectiveness of foreign trade.

The indicator of the integrated economic effect from the export-import activity of EEexp-imp can be calculated as follows:

$$
\mathrm{EE}_{\text {exp-imp }}=\mathrm{EE}_{\text {exp }}+\mathrm{EE}_{\text {imp }}
$$

where $E E_{\text {exp }}$ - the total economic impact of exports, reduced to the period of time for which the effect is determined, UAH .;

$E E_{\text {imp }}$ - the total economic impact of imports, reduced to the period for which the effect is determined, UAH.

The economic meaning of the integrated economic effect indicator shows the profit that the foreign trade participant had for the relevant period for the whole set of export-import operations.

The integrated indicator of the efficiency of export-import activity of the enterprise for the corresponding period is calculated:

$$
\mathrm{E}_{\text {exp-imp }}=\frac{\mathrm{EE}_{\text {exp-imp }}}{\left(B_{\text {exp }}-B_{\text {imp }}\right)}
$$

where $E E_{\text {exp-imp }}$ - integrated indicator of the effectiveness of export-import activities, kop. / UAH,\%;

$B_{\text {exp }}-$ full export costs, reduced to the period for which economic efficiency is determined, $\mathrm{UAH}$; $\mathrm{UAH}$

$B_{i m p}$ - total import costs, reduced to the period for which economic efficiency is determined, 
This indicator shows the efficiency of export-import activities, shows how many kopecks of profit the company has for each hryvnia costs associated with export-import operations.

According to the proposed scientific and methodological provisions, developing a scenario for the management of export-import activities of industrial enterprises in conjunction with the management of business processes should be presented in eight consecutive, interrelated stages, grouped into four levels (Fig. 4). The process begins with analyzing the problem, problem statement with the following definition and structuring the scope of research. Changes that occur in the internal or external environment that may hinder the achievement of goals are identified. Analysis of the state of the external and internal environment will clarify the objectives. After that, the tasks of organizing and stimulating the process of development and achievement of plans by all departments of the industrial enterprise are formulated. The goal-making process is carried out within the framework of variable planning.

Next, it is necessary to study the impact of the external environment on the problem that arises and to form requirements for alternative solutions. This refers to the second and seventh stages of the scenario development process, which can be attributed to the level of environmental problems. Given the fact that the scenarios have a long-term orientation, it is insufficient to analyze the current situation.

Figure 4. Stages of the scenario of management of export-import activity of industrial enterprises in interrelation with the management of business processes (source: developed by the authors)

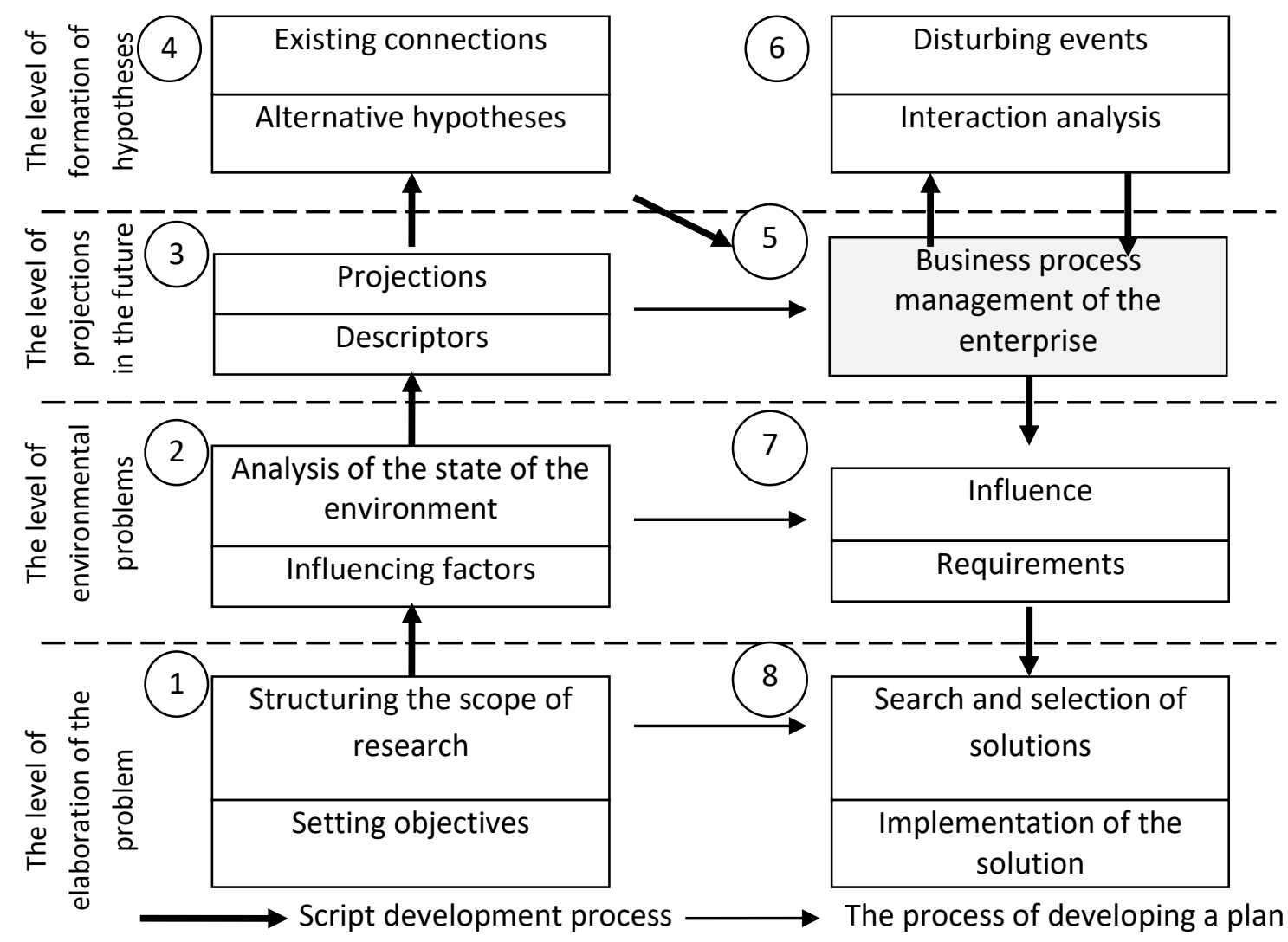

To characterize the predicted state of the environment, specific parameters (descriptors) are determined, and their possible development in the future is projected. Sets of projections of individual parameters allow making a scenario of business process management of an industrial enterprise, in particular an export strategy, on the basis of which conclusions are again made about the potential future impact on the problem (third and fifth stages of the scenario development process).

The level of achievement of goals, in this case, is determined by the coherence of all structural units of the enterprise and the degree of implementation of the developed measures. The final stage 
may be the detailing of measures and bringing them to a specific structural unit in the form of targets with a breakdown into specific time intervals and frameworks.

\section{Conclusions}

The main features of the digital economy are its global nature and the operation of intangible goods: ideas, information and relationships, network principles in the coordination of markets and society. In the digital economy, the world of subtle technologies controls machines; the virtual world changes real behaviour. It is these traits that create new types of markets and societies. The technological foundation of the digital economy is created on the basis of the discoveries of the fourth industrial revolution. Thus, enterprises need to improve approaches to business process management while entering foreign markets.

The proposed recommendations will help to better adapt to market conditions and build industrial enterprises, focus on export-import operations and manage business processes, which will ultimately have a positive impact on the performance of the entire enterprise.

\section{References}

1. Prokopenko, O., Shmorgun, L., Kushniruk, V., Prokopenko, M., Slatvinska, M., Huliaieva, L. (2020). Business process efficiency in a digital economy. International Journal of Management, Volume 11, Issue 3, pp. 122-132.

2. Binda, J., Prokopenko, M., Ramskyi, A., Shuplat, O., Halan, L., Mykhaylenko, D. (2020). Assessment of investment attractiveness of industrial enterprises. International Journal of Management, Volume 11, Issue 2, pp. 27-35.

3. Graham, M. (2010). The Digital Economy. Business Organisation, Production Processes, and Regional Developments. Regional Studies, 44(3), pp. 385-386. DOI: 10.1080/00343401003707375

4. Bashynska I. (2020). Management of industrial enterprise's business processes smartization to ensure its economic security. Schweinfurt: Time Realities Scientific Group UG (haftungsbeschränkt), $420 \mathrm{p}$.

5. Porter M.E. (1985). Competitive advantage: creating and sustaining superior performance. N.Y.: Free press, $658 \mathrm{p}$.

6. Luo, Ya., Zheng, Q., Jayaraman, V. (2010). Managing Business Process Outsourcing. Organizational Dynamics, 39(3), pp. 205-217. DOI: 10.1016/j.orgdyn.2010.03.005

7. El-Mekawy, M., Shahzad, K., Ahmed, N. (2010). Modeling and Managing Business Processes. Handbook on Business Information Systems, pp. 93-116.

https://doi.org/10.1142/9789812836069_0005

8. Gryshchenko, I., Chubukova, O., Bilovodska, O., Gryshchenko, O., Melnyk, Y. (2020). Marketingoriented approach to evaluating the strategy of distribution management for innovative products in logistics. WSEAS Transactions on Environment and Development, 16, pp. 371-383.

9. Kasych, A., Kozhemiakina, S., Vochozka, M., Romanenko, O., Glukhova, V. (2019). A World Model of Social Entrepreneurship in a Crisis. Journal of Entrepreneurship Education Research, 22. https://www.abacademies.org/articles/a-world-model-of-social-entrepreneurship-in-a- crisis8049.html

10.State Statistics Service of Ukraine http://www.ukrstat.gov.ua/

11.Malyarets, L. (2021). Diagnostics of Efficiency of an Enterprise's Export-import Activity. Montenegrin journal of economics, 17(1), pp. 71-83. DOI: 10.14254/1800-5845/2021.17-1.5

12.Malyarets, L., Grynko, P. (2019). Analytical Support for Analysis of Efficiency of an Enterprise's Export-Import Activity. The problems of economy, 1(39), pp. 208-216.DOI: 10.32983/2222-07122019-1-208-216 
13.Kuzmin, O., Zhyhalo, O. (2020). Development of Customs Regulation of Export-Import Activities in the Conditions of Using the Innovative Capacity of Enterprises. Business Inform, 4(507), pp. 28-34. DOI: 10.32983/2222-4459-2020-4-28-34 